\title{
PENGARUH MEDIA PEMBELAJARAN ZOOM MEETING TERHADAP HASIL BELAJAR IPS PADA MASA COVID-19 DI SMP SHIDQIA ISLAMIC SCHOOL BEKASI
}

\author{
Desiana Andika Putri, Irvia Eriza \\ Universitas Panca Sakti Bekasi Jawa Barat, Indonesia \\ Email: ddesianaputri@gmail.com, erizairvia@gmail.com
}

\begin{abstract}
Abstrak
Pada saat ini, dunia sedang dihadapi dengan fenomena pandemic Covid-19. Dalam rangka meminimalisir penyebaran virus Covid-19, pemerintah mengambil kebijakan dengan social distancing termasuk kebijakan bidang pendidikan melalui penyelenggaraan belajar dari rumah physical distancing, study from home. penerapan metode zoom meeting dalam proses study from home dapat memberikan pembelajaran yang efektif seperti adanya umpan balik terkait, menggabungkan kolaborasi kegiatan belajar mandiri, serta personalisasi pembelajaran yang berdasarkan kebutuhan peserta didik menggunakan tanya jawab dengan berkomunikasi langsung dengan pendidik. Dengan tetap mengikuti aturan Social Distancing. Tujuan penelitian ini adalah untuk mengetahui apakah ada pengaruh dalam penerapan media pembelajaran zoom meeting dalam proses study from home terhadap hasil belajar IPS kelas 8 di SMP Shidqia Islamic School. Metode penelitian ini menggunakan metode eksperimen dengan bentuk penilaian pretest dan posttest. Hasil penelitian ini dapat disimpulkan bahwa terdapat pengaruh positif penggunaan media zoom meeting terhadap hasil belajar IPS kelas VIII di SMP Shidqia Islamic School, besarnya presentase pengaruh variabel bebas (Zoom Meeting) terhadap variabel terikat (Hasil Belajar IPS) yang disebut koefisien determinasi/R squeare (R2) yaitu sebesar 0,264, yang mengandung pengertian bahwa pengaruh Media pembelajaran online zoom Meeting terhadap hasil belajar IPS adalah sebesar $26,4 \%$.
\end{abstract}

Kata Kunci: zoom meeting; hasil belajar \& IPS; Covid

\section{Abstract}

At this time, the world is facing the phenomenon of the Covid-19 pandemic. In order to minimize the spread of the Covid-19 virus, the government has taken a policy of Social Distancing, including policies in the field of education through the implementation of learning from home, physical distancing, study from home. the application of the zoom meeting method in the study from home process can provide effective learning such as related feedback, combining collaborative independent learning activities, and personalizing learning based on the needs of students using question and answer by communicating directly with educators. By still following the rules of Social Distancing. The purpose of this research is to find out whether there is an influence in the application of the zoom meeting method in the study from home process on the social studies learning outcomes for class VIII in SMP Shidqia

$\begin{array}{ll}\text { How to cite: } & \text { Putri, D. A., \& Eriza, I. (2021) Pengaruh Media Pembelajaran Zoom Meeting terhadap Hasil Belajar } \\ & \text { IPS pada Masa Covid-19 Di SMP Shidqia Islamic School Bekasi, Syntax Idea, 3(8). } \\ & \text { https://doi.org/10.36418/syntax-idea.v6i8.1428 } \\ \text { E-ISSN: } & \text { 2684-883X } \\ \text { Published by: } & \text { Ridwan Institute }\end{array}$


Islamic School, this research method uses the experiment with the form of Pretest and Posttest assessment. The results of this study can be concluded that there is a Positive effect of using zoom meeting media on Social Sudies learning outcomes for class VIII in SMP Shidqia Islamic School, the percentage of the influence of the independent variable (Zoom Meeting) on the dependent variable (IPS Learning Outcomes) called the coefficient of determination / $R$ square $(R 2)$ is 0.264, which implies that the influence of Zoom Meeting online learning media on social studies learning outcomes is $26.4 \%$.

Keywords: zoom meeting; learning outcomes \& social studies; covid

\section{Pendahuluan}

Pada masa sekarang ini, dunia sedang dihadapkan dengan fenomena pandemic Covid-19 termasuk negara Indonesia, oleh sebab itu pemerintah mengambil kebijakan dengan menerapkan social distancing dalam rangka meminimalisir penyebaran virus Covid-19. Termasuk kebijakan dalam bidang pendidikan dalam penerapan proses pembelajaran. Maka dari itu, dikeluarkannya kebijakan Pemerintah Republik Indonesia melalui Surat Edaran Sekretaris Jenderal Kemendikbud RI Nomor 15 Tahun 2020 tanggal 18 Mei 2020, menginstruksikan bahwa dalam rangka pemenuhan hak peserta didik untuk mendapatkan layanan pendidikan selama darurat penyebaran Corona Virus Diseas (Covid-19) melalui penyelenggaraan belajar dari rumah tersebut merupakan bagian dari program kebijakan pemerintah tentang physical distancing, study from home untuk mencegah penularan virus corona atau covid-19.

Belajar dari rumah (study from home) dapat diartikan pembelajaran melalui daring yang dilakukan secara online. Pembelajaran online yaitu suatu kegiatan belajar yang memerlukan jaringan internet dengan konektivitas, aksesbilitas, fleksibilitas, dan juga kemampuan untuk memunculkan berbagai macam jenis interaksi pembelajaran (Handarini \& Wulandari, 2020).

Menurut (Rusli, Hermawan, Supuwiningsih, \& Bali, 2017) pembelajaran online yang berpusat kepada peserta didik dengan menggunakan media pembelajaran elektronik atau media pembelajaran berbasis multimedia. Peneliti menyimpulkan pembelajaran online yakni kegiatan proses belajar mengajar yang dilakukan oleh peserta didik sebagai pusat pembelajaran dengan menggunakan media elektronik sebagai bahan ajarnya yang terhubung pada jaringan internet.

Ketika melaksanakan pembelajaran secara online pastinya memerlukan media pembelajaran sebagai sarana untuk pembelajaran. Oleh karena itu, berbagai macam platform pendidikan digunakan sebagai media pembelajaran oleh sekolah maupun universitas. Di sekolah sendiri terdapat berbagai macam platform pendidikan yang digunakan seperti Google Classroom, Zoom Meeting, WhtasApp, Google Meet, dan sebagainya.

Beberapa penelitian terdahulu menunjukkan bahwa pembelajaran Online menggunakan platform konferensi seperti Zoom berdampak positif terhadap belajar siswa termasuk proses menghafal. Tujuan dari penelitian ini adalah untuk mengungkap 
keaktifan siswa dalam pembelajaran hafalan Al-Qurean menggunakan Zoom (Syarif \& Kholis, 2020).

Media pembelajaran menurut adalah sebagai alat, merode, dan teknik yang digunakan dalam rangka lebih mengefektifkan komunikasi dan interaksi antara guru dengan peserta didik dalam proses pendidikan dan pengajaran disekolah. Media pembelajaran ialah segala sesuatu yang dapat dimanfaatkan untuk menyampaikan pesan dari pengirim ke penerima sehingga dapat merangsang pikiran, perasaan, perhatian, dan minat serta motivasi peserta didik sedemikian rupa sehingga proses belajar terjadi.

Media pembelajaran dapat diartikan dengan berbagai cara. Ada yang mengartikan secara luas, yaitu setiap orang, materi ayau peristiwa yang memberikan kesempatan kepada peserta didik untuk mendapatkan pengetahuan, keterampilan dari sikap. Dengan demikian, tenaga pendidik, buku pelajaran, dan bangunan sekolah menjadi suatu medium pengajaran. Ada pula yang mengartikan istilah itu secara sempit, yaitu alat-alat yang menjadi perantara peserta didik dan materi pelajaran.

Beberapa Manfaat media dalam pembelajaran menurut kemampuan Dayton adalah yang pertama penyampaian materi pelajaran dapat disamakan, kedua proses pembelajaran menjadi lebih efektif dan menarik, ketiga proses pembelajaran menjadi lebih interaktif, keempat efisiensi waktu dan tenaga, kelima meningkatkan kualitas hasil belajar peserta didik, keenam memungkinkan proses belajar dapat dilakukan dimana saja dan kapan saja, ketujuh menumbuhkan sikap positif peserta didik terhadap materi dan proses belajar, dan kedelapan merunah peran pengajar ataupun guru ke arah yang lebih baik dan produktif.

Zoom Meeting sendiri yakni sebuah media pembelajaran menggunakan video. Pendiri aplikasi Zoom Meeting yaitu Eric Yuan yang diresmikan tahun 2011, kantor pusatnya berada di San Jose, California. Aplikasi ini tidak hanya digunakan untuk pembelajaran saja, tetapi bisa juga digunakan untuk kegiatan perkantoran maupun kegiatan lainnya. Platform ini tidak berbayar, jadi dapat digunakan oleh siapa saja dengan batas waktu empat puluh menit dan jika akun zoom meeting berbayar maka tidak ada batasan waktu dalam penggunaannya.

Menurut (Widyaningrum, 2020) video conference zoom meeting dinilai efektif dalam menangani masalah ruang jarak, dan juga waktu. Menurut (Ismawati \& Prasetyo, 2020) pembelajaran dengan zoom meeting mampu memaksimalkan kreativitas dalam pembelajaran. Menurut (Sandiwarno, 2016) pembelajaran melalui video conference selain dapat memaksimalkan adanya interaksi secara langsung antara peserta didik, pendamping anak belajar dan pendidik, juga dapat menyuguhkan materi pembelajaran ditampilan dan dapat dilihat oleh semua partisipan, sehingga partisipan tidak hanya mendengar penjelasan melainkan juga dapat mencermati dan memperhatikan materi yang diberikan.

Pembelajaran menggunakan zoom meeting dapat membantu peserta didik dan pendidik untuk beradaptasi melakukan pembelajaran jarak jauh. Menurut (Dharma, Asmarani, \& Dewi, 2017) pembelajaran dengan menggunakan zoom meeting membantu pendidik dapat menilai perkembangan dan juga keaktifan peserta didik 
secara langsung zoom meeting dapat menjadi sarana sebagai wadah belajar jarak jauh untuk peserta didik, memberikan peluang bagi peserta didik untuk berperan aktif dalam proses pembelajaran, dan dapat memberikan akuisisi bagi peserta didik.

Menurut (Muhibbin, 2010) mengutarakan bahwa seorang ahli psikolog bernama Wittig dalam bukunya psychology of learning mendefinisikan belajar sebagai: "any relatively permanent change in an organism's behavioral repertoire that occurs as a result of experience, artinya belajar adalah perubahan yang relatif menetap yang terjadi dalam berbagai macam atau keseluruhan tingkah laku suatu organisme sebagai hasil pengalaman.

Menurut (Slameto, 2013) Pengertian belajar dapat diartikan sebagai suatu proses usaha yang dilakukan seseorang untuk memperoleh suatu perubahan tingkah laku yang baru secara keseluruhan, sebagai hasil pengalamannya sendiri dalam interaksi dengan lingkungannya.

Menurut (Hamalik, 1994) memaparkan bahwa hasil belajar bukan suatu penguasaan hasil latihan melainkan perubahan kelakuan. Hasil belajar ialah kemampuan-kemampuan yang dimiliki siswa setelah siswa menerima pengalaman belajarnya (Sudjana, 2014). Hasil belajar merupakan hasil dari suatu interaksi tindak belajar dan tindak mengajar (Dimyati, 2009).

Menurut (Sudijono, 2012) memaparkan bahwa hasil belajar merupakan sebuah tindakan evaluasi yang dapat mengungkapkan aspek proses berpikir (cognitive domain) juga dapat mengungkap aspek kejiwaan lainnya, yaitu aspek nilai atau sikap (affective domain) dan aspek keterampilan (psychomotor domain) yang terdapat pada diri setiap individu peserta didik. Ini artinya melalui hasil belajar dapat diketahui secara holistic penggambaran pencapaian siswa setelah melalui pembelajaran. Dari uraian di atas dapat ditarik kesimpulan bahwa hasil belajar adalah suatu perubahan yang diperoleh setelah mengalami proses belajar.

IPS pada kurikulum sekolah (satuan pendidikan), pada hakikatnya ialah mata pelajaran wajib sebagaimana dituangkan dalam Undang Undang Nomor 20 Tahun 2003 tentang Sistem Pendidikan Nasional pada pasal 37 yang berbunyi bahwa kurikulum pendidikan dasar dan menengah wajib memuat ilmu pengetahuan social.

Menurut (Hidayati, 2008) Ilmu Pengetahuan Sosial (IPS) yaitu sebuah pendekatan interdisipliner dari ilmu-ilmu sosial. Ilmu Pengetahuan Sosial (IPS) merupakan integrasi dari berbagai cabang ilmu-ilmu sosial seperti sosiologi, antropologi budaya, psikologi sosial, sejarah, geografi, ekonomi, ilmu politik, dan sebagainya.

Dari berbagai macam pendekatan yang diungkapkan oleh para ahli, maka pada hakikatnya mata pelajaran IPS untuk tingkat SMP dan MTs adalah integrasi dan penyederhanaan dari berbagai macam displin ilmuilmu sosial yang disusun secara sistematis, komprehensif, dan terpadu.

Tujuan IPS (Supardi., 2011) yaitu menjadikan siswa sebagai warga negara yang baik, mengembangkan kemampuan berpikir kritis dan inkuiri, melatih belajar mandiri, mengembangkan kecerdasan dan keterampilan sosial, menghayati nilai moral, serta mengembangkan kesadaran dan kepedulian terhadap masyarakat dan lingkungan. 
IPS di tingkat sekolah pada dasarnya memiliki tujuan untuk mempersiapkan peserta didik sebagai warga yang menguasai pengetahuan (knowledge), keterampilan (skill), sikap dan nilai (attitudes and value) (Sapriya, 2009) Pengetahuan, keterampilan dan sikap tersebut dapat digunakan sebagai kemampuan untuk memecahkan masalah pribadi atau masalah sosial serta kemampuan mengambil keputusan dan turut serta dalam berbagai macam kegiatan masyarakat agar menjadi warga negara yang baik.

Jika merujuk pada 4 tujuan dasar pembelajaran IPS menurut (Ryan, 1971) pemahaman skill, nilai dan sikap serta proses berpikir, hal ini berarti terdapat 3 kompetensi yang harus dimiliki siswa setelah mengikuti pembelajaran IPS yaitu pengetahuan yang semakin bertambah, sikap senantiasa yang semakin baik, dan juga keterampilan dalam menyelesaikan masalah yang ada pada diri dan lingkungan.

Penelitian ini sangat bermanfaat bagi guru maupun peserta didik, karena hasil dari penelitian ini kita dapat mengetahui seberapa besar pengaruh penggunaan Zoom Meeting terhadap hasil belajar siswa. Sehingga pencapaian hasil belajar yang maksimal bisa didapatkan.

Penelitian ini bertujuan untuk mengetahui seberapa besar pengaruh penggunaan Zoom Meeting sebagai media pembelajaran di Masa Pandemi Covid-19 terhadap hasil belajar siswa pada mata pelajaran IPS di SMP Shidqia Islamic School.

\section{Metode Penelitian}

Penelitian ini dilakukan di SMP Shidqia Islamic School Bekasi pada siswa kelas 8 Sevilla Tahun Pelajaran 2020/2021. Penelitian ini termasuk pada penelitian kuantitatif. Metode penelitian yang digunakan adalah eksperimen dengan bentuk one group pretest posttest design. Populasi dalam penelitian ini ialah seluruh siswa kelas 8 Sevilla berjumlah 21 siswa. Sampel pada penelitian ini menggunakan Non Probabilty Sampel dengan Samping Jenuh (Boring Sampilng). Metode analisis data yang digunakan yaitu menggunakan uji t.

\section{Hasil dan Pembahasan}

Tabel 1

Data Statistik

\begin{tabular}{lcr}
\hline \multicolumn{3}{c}{ Statistics } \\
\hline & Pretest & Posttest \\
\hline N Valid & \multicolumn{1}{c}{$\mathbf{2 1}$} & \multicolumn{1}{c}{$\mathbf{2 1}$} \\
\hline \multicolumn{1}{c}{ Missing } & \multicolumn{1}{c}{ 0 } & \multicolumn{1}{c}{ 0 } \\
\hline Mean & 78.00 & 85.81 \\
Median & 75.00 & 87.00 \\
Mode & 75 & 93 \\
Std. Deviation & 6.205 & 7.580 \\
Variance & 38.500 & 57.462 \\
Range & 25 & 25 \\
Minimum & 75 & 75 \\
Maximum & 100 & 100 \\
Sum & 1638 & 1802 \\
\hline
\end{tabular}


Berdasarkan pada data diatas dapat dilihat bahwa dari responden yang berjumlah 21 siswa didapat bahwa nilai terendah untuk Pretest adalah 75 dan nilai tertinggi 100, mean sebesar 78,00 dan simpan bakunya 6,205. Sedangkan untuk Posttest didapat bahwa nilai terendah 75 , nilai tertinggi 100 , dengan mean sebesar 85,81 dan besarnya simpanan bakunya adalah 7,580.

\section{Tabel 2}

Uji Normalitas Skor Hasil Belajar

\begin{tabular}{|c|c|c|c|}
\hline \multicolumn{4}{|c|}{ One-Sample Kolmogorov-Smirnov Test } \\
\hline & & Pretest & Posttest \\
\hline $\mathrm{N}$ & & 21 & 21 \\
\hline \multirow{2}{*}{ Normal Parameters ${ }^{\mathrm{a}}$} & Mean & 78.00 & 85.81 \\
\hline & Std. Deviation & 6.205 & 7.580 \\
\hline \multirow{4}{*}{$\begin{array}{l}\text { Most Extreme } \\
\text { Differences }\end{array}$} & Absolute & .352 & .210 \\
\hline & & & \\
\hline & Positive & .352 & .207 \\
\hline & Negative & -.314 & -.210 \\
\hline \multicolumn{2}{|c|}{ Kolmogorov-smirnov Z } & 1.614 & .960 \\
\hline \multicolumn{2}{|c|}{ Asymp. Sig. ( 2-tailed) } & .011 & .315 \\
\hline \multicolumn{2}{|c|}{ a. Test distribution is Normal } & & \\
\hline
\end{tabular}

Dari data Tabel 2, diperoleh Kolmogorov-Smimov untuk Pretest adalah 1,614 dan Posttest adalah 0.960 itu berarti semua sampel lebih besar dari 0,05 sehingga $\mathrm{H}_{0}$ diterima. Dengan kata lain bahwa semua sampel pada penelitian ini berdistribusi Normal.

Tabel 2

Persamaan Regresi Linear

\begin{tabular}{|c|c|c|c|c|c|c|}
\hline \multicolumn{7}{|c|}{ Coefficients $^{\mathrm{a}}$} \\
\hline & \multirow[t]{2}{*}{ Model } & \multicolumn{2}{|c|}{$\begin{array}{c}\text { Unstandardized } \\
\text { Coefficients }\end{array}$} & \multirow{2}{*}{$\begin{array}{c}\begin{array}{c}\text { Standardized } \\
\text { Coefficients }\end{array} \\
\text { Beta } \\
\end{array}$} & \multirow[t]{2}{*}{$\mathbf{t}$} & \multirow[t]{2}{*}{ Sig. } \\
\hline & & $\mathrm{B}$ & Std. Error & & & \\
\hline 1 & (Constant) & 36.882 & 18.816 & & 1.960 & .065 \\
\hline & Pretest & .627 & .241 & .513 & 2.608 & .017 \\
\hline
\end{tabular}

a. Dependent Variable

Dilihat dari tabel 2 kolom B diperoleh persamaan regresi: $\mathrm{Y}=36,882+0,627 \mathrm{X}$. Hasil analisis diperoleh $\mathrm{t}_{\text {hit }}=2,608$ dan $\mathrm{p}$-value $=0,017<0,05$ atau $\mathrm{H}_{0}$ ditolak. Dengan demikian Media Pembelajaran Zoom Meeting berpengaruh POSITIF terhadap Hasil Belajar IPS. 
Tabel 3

Uji Signifikansi Persamaan Regresi

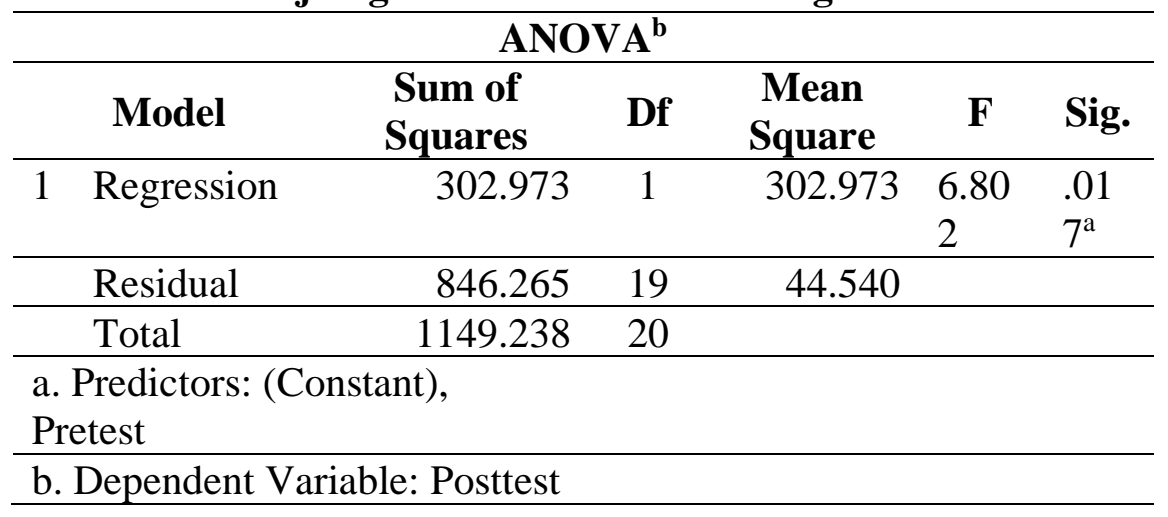

Hipotesis statistic:

Ho: $b=0$ (regresi tak berarti)

Hi: $b=0$ (regresi berarti)

Uji signifikansi persamaan garis regresi diperoleh dalam tabel ANOVA ini didapatkan bahwa $\mathrm{F}$ hitung = 6,802 dengan tingkat signifikansi/Probabilitas ( $\mathrm{p}$-value) = $0,017<0,05$ atau Ho ditolak, maka model regresi dapat dipakai untuk memprediksi variable partisipasi. Dengan demikian, regresi $\mathrm{Y}$ atau $\mathrm{X}$ adalah signifikan dan hipotesis penelitian didukung oleh data empiris.

Tabel 4

Uji Signifikansi Koefisien Korelasi

\begin{tabular}{|c|c|c|c|c|c|c|c|}
\hline \multicolumn{8}{|c|}{ Model Summaryb } \\
\hline \multirow[t]{2}{*}{ Model } & $\mathbf{R}$ & R & $\begin{array}{c}\text { Adjusted } \\
\mathbf{R}\end{array}$ & $\begin{array}{c}\text { Std. Error } \\
\text { of the }\end{array}$ & & Change Statistics & \\
\hline & & & & & $\begin{array}{l}\mathrm{R} \\
\text { Square } \\
\text { Change }\end{array}$ & $\begin{array}{lll}\text { F } & \text { df1 } & \text { df2 } \\
\text { Cha } & & \\
\text { nge } & & \end{array}$ & $\begin{array}{l}\text { Sig. F } \\
\text { Change }\end{array}$ \\
\hline 1 & $.513^{\mathrm{a}}$ & .264 & .225 & 6.674 & .264 & $\begin{array}{rrr}6.80 & 1 & 19 \\
2 & & \end{array}$ & .017 \\
\hline
\end{tabular}

a. Predictors: (Constant), Pretest

b. Dependent Variable: Posttest

Hipotesis statistic:

$\mathrm{H}_{0}: \mathrm{p}=0$

$\mathrm{H}_{1}: \mathrm{p} \neq 0$

Uji signifikansi koefisien korelasi diperoleh dari tabel Model Summary. Tabel diatas menunjukkan bahwa besarnya nilai koefisien korelasi/hubungan (R) yaitu sebesar 0,569 dan $\mathrm{F}$ hit $\left(\mathrm{F}_{\text {change }}\right)=6,802$, dengan $\mathrm{p}$-value $=0,017<0,05$. Hal ini berarti $\mathrm{H}_{\mathrm{o}}$ ditolak, artinya koefisien korelasi $\mathrm{X}$ dan $\mathrm{Y}$ adalah berarti atau signifikan. Sedangkan 
besarnya presentase pengaruh variabel bebas (Zoom Meeting) terhadap variable terikat (Hasil Belajar IPS) yang disebut koefisien determinasi/ R square (R2) yaitu sebesar 0,264, yang mengandung pengertian bahwa pengaruh Media Pembelajaran online Zoom Meeting terhadap Hasil Belajar IPS adalah sebesar 26,4\%. Sedangkan sisanya (100\% $26,4=73,6 \%$ ) dipengaruhi oleh variable lain di luar variable yang tidak diteliti.

\section{Kesimpulan}

Berdasarkan analisis data dari penelitian dapat disimpulkan bahwa media pembelajaran Zoom Meeting berpengaruh positif terhadap Hasil Belajar IPS. Hal ini dibuktikan dengan diperoleh persamaan regresi: Y Error! Reference source not found. $36,882+0,627 \mathrm{X}$. Hasil analisis diperoleh $\mathrm{t}_{\text {hit }}=2,608$ dan $\mathrm{p}$ - value $=0,017<0,05$ atau $\mathrm{H}_{0}$ ditolak. Sedangkan besarnya presentase pengaruh variable bebas (Zoom Meeting) terhadap variable terikat (Hasil Belajar IPS) yang disebut koefisien determinasi/ $\mathrm{R}$ squeare (R2) yaitu sebesar 0,264, yang mengandung pengertian bahwa pengaruh Media Pembelajaran online Zoom Meeting terhadap hasil belajar IPS adalah sebesar 26,4\% . 


\section{BIBLIOGRAFI}

Dharma, Hendy Reginald Cuaca, Asmarani, Dhaniar, \& Dewi, Udiana Puspa. (2017). Basic Japanese grammar and conversation e-learning through Skype and Zoom online application. Procedia Computer Science, 116, 267-273. Google Scholar

Dimyati, Mudjiono. (2009). Belajar dan Pembelajaran. Jakarta: PT. Rineka Cipta.

Hamalik, Oemar. (1994). Media Pendidikan. Bandung: Alumni.

Handarini, Oktafia Ika, \& Wulandari, Siti Sri. (2020). Pembelajaran daring sebagai upaya study from home (SFH) selama pandemi covid 19. Jurnal Pendidikan Administrasi Perkantoran (JPAP), 8(3), 496-503. Google Scholar

Hidayati, dkk. (2008). Pengembangan Pendidikan IPS SD. Direktorat Jenderal Pendidikan Tinggi Departemen Pendidikan Nasional.

Ismawati, Dwi, \& Prasetyo, Iis. (2020). Efektivitas pembelajaran menggunakan video zoom cloud meeting pada anak usia dini era pandemi covid-19. Jurnal Obsesi: Jurnal Pendidikan Anak Usia Dini, 5(1), 665. Google Scholar

Muhibbin, Syah. (2010). Psikologi pendidikan dengan pendekatan baru. Bandung: PT Remaja Rosdakarya. Google Scholar

Rusli, Muhammad, Hermawan, Dadang, Supuwiningsih, Ni Nyoman, \& Bali, STIKOM. (2017). Multimedia pembelajaran yang inovatif: Prinsip dasar dan model pengembangan. Penerbit Andi. Google Scholar

Ryan, Frank L. (1971). Exemplars for the new social studies: Instructing in the elementary school. Prentice-Hall. Google Scholar

Sandiwarno, Sulis. (2016). Perancangan Model E-Learning Berbasis Collaborative Video Conference Learning Guna Mendapatkan Hasil Pembelajaran yang Efektif dan Efisien. Jurnal Ilmiah FIFO, 8(2), 191. Google Scholar

Sapriya, S. (2009). Pendidikan IPS Konsep dan Pembelajaran. Bandung: PT Remaja Rosda Karya. Google Scholar

Slameto, Drs. (2013). Belajar \& faktor-faktor yang mempengaruhi. Jakarta: Rineka Cipta. Google Scholar

Sudijono, A. (2012). Pengantar evaluasi pendidikan. Jakarta: PT. RajaGrafindo Persada. Rya, Frank L. 1971. Examplars For The New Social Studies: Instructing in the Elementary School. Prentice - Hall: New Jersey.

Sudjana, Nana. (2014). Penilaian hasil proses belajar mengajar. Katalog online perpustkaan FIP UNY. Google Scholar 
Supardi. (2011). Dasar-Dasar Ilmu Sosial. Yogyakarta: Penerbit Ombak.

Syarif, Syarif, \& Kholis, Nur. (2020). Keaktifan Siswa Dalam Pembelajaran Hafalan Al-Qur'an Menggunakan Zoom: Studi Pada Siswa Kelas 8 SMP Ar-Rahmah Malang. Al-Tadzkiyyah: Jurnal Pendidikan Islam, 11(2), 275-293. Google Scholar

Widyaningrum, Dian Permanasari. (2020). The Effect Of Zoom Meeting On E-Learning Based Remote Learning In Improving Student Cognitive Ability. Mataazir: Jurnal Administrasi Dan Manajemen Pendidikan, 1(2), 62-77. Google Scholar

\section{Copyright holder:}

Desiana Andika Putri, Irvia Eriza (2021)

\section{First publication right:}

Syntax Idea

This article is licensed under: 